\title{
PEMANFAATAN MEDIA SOSIAL TIK TOK SEBAGAI MEDIA KAMPANYE GERAKAN CUCI TANGAN DI INDONESIA UNTUK PENCEGAHAN CORONA COVID-19
}

\author{
1) Togi Prima Hasiholan, ${ }^{2)}$ Rezki Pratami, ${ }^{3)}$ Umaimah Wahid \\ ${ }^{1,2,3)}$ Fakultas Ilmu Komunikasi, Universitas Budi Luhur \\ 1,2,3) J1.Ciledug Raya Petukangan Utara, Jakarta Selatan 12260 - Indonesia \\ E-mail : togiprima@gmail.com,rezkypratami@gmail.com,umaimah.wahid@budiluhur.ac.id
}

\begin{abstract}
ABSTRAK
Indonesia yang sebanyak 64,8\% penduduknya sudah menggunakan Internet dan 160 Juta jiwa merupakan pengguna sosial media, membuat Indonesia merupakan pasar yang menjanjikan oleh para pelaku industry sosial media, seperti aplikasi Tik Tok. Ditahun 2020 aplikasi Tik Tok menjadi budaya populer di Indonesia, karena masyarakat Indonesia pasti mengetahui aplikasi iini dan menjadi penggunanya.Populernya Tik Tok di Indonesia menjadi media yang ideal oleh World Health Organization (WHO) yang mengkampanyekan gerakan cuci tangan yang benar untuk memutus penularan Virus COVID-19 atau yang dikenal dengan nama corona dengan memproduksi video serta hastag \#safehands challenge di aplikasi Tik Tok yang selanjutnya para creator memproduksi konten video versi mereka sendiri dan menambahkan hastag \#safehands challenge untuk mengikuti challenge ini.Kampanye lewat video dengan hastag \#safehands challenge ini banyak disaksikan, namun ada beberapa point yang mendasari video mana yang paling banyak disaksikan,sukai dan share oleh pengguna Tik Tok.
\end{abstract}

Kata Kunci: Tik Tok, Kampanye,Cuci Tangan,COVID-19,\#Safehands.

\begin{abstract}
Indonesia, which is $64.8 \%$ of the population, has used the Internet and 160 million people are social media users, making Indonesia a promising market by social media industry players, such as the Tik Tok application. In 2020 the Tik Tok application became a popular culture in Indonesia, because the Indonesian people would know this application and become its user. The popularity of Tik Tok in Indonesia became an ideal medium by the World Health Organization (WHO) which campaigns for the correct hand washing movement to break the transmission of the COVID Virus -19 or known by the name of corona by producing videos and hashtags \#safehands challenge in the Tik Tok application, then the creators produce their own version of video content and add hashtags \#safehands challenge to follow this challenge. Campaigning via video with this \#safehands challenge hashtag watched a lot, but there are some points that underlie which videos are most watched, liked and shared by Tik Tok users.
\end{abstract}

Keyword: Tik Tok, Campaign, Handwashing, COVID-19, \# Safehands 


\section{PENDAHULUAN}

\section{A. Latar Belakang}

Indonesia saat ini berdasarkan hasil studi Polling Indonesia yang bekerjasama dengan Asosiasi Penyelenggara Jasa Internet Indonesia (APJII) mendapatkan bahwa sebanyak 171,17 juta jiwa atau bila dipersentasekan sekitar $64,8 \%$ penduduk Indonesia merupakan pengguna Internet. Angka yang sangat besar ini tentunya membuat masyarakat Indonesia mengalami perubahan budaya dalam bermedia saat ini, karena tentunya terdapat peralatan dan prosedur baru yang akan diadaptasi oleh masyarakat itu sendiri dalam penggunaanya. (https://katadata.co.id/berita/2019/05/16/survei-apjii-penetrasi-pengguna-internet-di-indonesiacapai-648)

Perubahan budaya bermedia tersebut membuat masyarakat saat ini banyak bermedia dengan menggunakan beragam gawai yang semakin canggih di era konvergensi saat ini, berdasarkan data dari We are Social di tahun 2020 didapatkan mobile phone (96\%) dan smartphone (93\%) menjadi gawai yang paling banyak digunakan oleh pengguna internet di Indonesia yang berkisar usia 16-64 tahun.( https://inet.detik.com/cyberlife/d-4907674/riset-ada1752-juta-pengguna-internet-di-indonesia). Pada 2020 ini juga tercatat pengguna sosial media di Indonesia mengalami kenaikan sekitar 10 juta jiwa dari tahun sebelumnya, yakni tercatat sebanyak 160 Juta orang Indonesia yang aktif di sosial media pada tahun 2020.

Pada tahun 2020 ini di Indonesia, sosial media yang mengalami perkembangan pesat hingga menjadi budaya populer di Indonesia adalah aplikasi Tik Tok. Sebenarnya aplikasi Tik Tok bukanlah sosial media yang baru di Indonesia, karena pada beberapa tahun belakangan di tahun 2018 hingga 2019 Tik Tok sudah mulai dikenal di Indonesia, akan tetapi pada saat itu Tik Tok kadung menjadi aplikasi digital berbasis video yang mengeluarkan output yang sifatnya membodohkan. Bahkan, fenomena internet mengamini itu saat pengguna mengetik 'aplikasi bodoh' pada kolom alamat yang kosong. Puncaknya dari itu semua adalah saat Tik Tok diblokir oleh Kementerian Komunikasi dan Informatika, dengan alasan Tik Tok memproduksi konten negatif, terutama bagi kalangan anak-anak. (https://kominfo.go.id/content/detail/13331/inipenyebab-kominfo-putuskan-blokir-tik-tok/0/sorotan_media)

Dua tahun dari Tik Tok di blokir oleh Kementerian Komunikasi dan Informatika, kini Tik Tok menjadi trend baru dan budaya populer di Indonesia. Budaya Populer merupakan budaya yang disukai oleh banyak orang dan tidak terikat dengan kelas sosial tertentu, budaya populer saat ini semakin besar dampaknya di era digital saat ini, karena Kemudahan akses ke informasi memiliki dampak signifikan pada budaya populer yang ada di suatu negara (Sorrels, 2015). Perkembangan suatu budaya populer saat ini di Indonesia sangat besar peran generasi millennial, karena para millennial sangat aktif dan intens dengan teknologi baru, salah satunya adalah 
aplikasi Tik Tok yang banyak di gunakan generasi millennial di Indonesia dan menjadikannya budaya populer di Indonesia.

Dimasa pandemik corona covid-19 di seluruh dunia, termasuk di Indonesia yang hingga saat ini jumlah korban yang meninggal mencapai 136 Jiwa dari 1.528 kasus tentunya banyak pihak baik yang memutus penyebaran covid-19 di seluruh dunia. Salah satu cara untuk memutus rantai penyebaran covid-19 adalah rajin melakukan cuci tangan dengan sabun. (https://www.cnnindonesia.com/nasional/20200331120413-20-488607/update-corona-31-maret1528-kasus-136-meninggal-81-sembuh). Untuk menggalakan cuci tangan dengan sabun di masa pandemic corona covid-19 saat ini tentunya dapat dilakukan dengan beragam cara, dan salah satunya dengan melakukan sosialisasikepada msayarakat luas.Penggunaan budaya populer seperti Tik Tok pun digunakan sebagai media sosialisasi cuci tangan dengan sabun.

Permasalahan terkait sosialisasi cuci tangan yang baik dan benar di masa pandemik corona covid-19 yakni adanya keterbatasan waktu dan larangan berkumpul, maka diperlukan cara lain untuk mensosialisasikannya, yakni dengan menggunakan budaya yang sedang populer di Indonesia saat ini, yakni aplikasi Tik Tok.Berdasarkan uraian latar belakang diatas, penulis akan membahas "Pemanfaatan Media Sosial Tik Tok Sebagai Media Kampanye Gerakan Cuci Tangan Di Indonesia untuk pencegahan Corona COVID-19"

\section{METODE}

Penelitian ini membahas Pemanfaatan Media Sosial Tik Tok Sebagai Media Kampanye Gerakan Cuci Tangan Di Indonesia untuk pencegahan Corona COVID-19. Penelitian ini dilaksanakan pada Maret - April 2020, dengan tahap dari penelusuran pustaka, interpretasi terhadap data dan juga wawancara dengan informan.

Jenis penelitian yang digunakan dalam penelitian ini adalah metode kualitatif dengan pendekatan deskriptif. Penelitian dengan pendekatan Kualitatif deskriptif fokus pada suatu unit tertentu dari berbagai fenomena, sehingga memungkinkan studi ini dapat dilakukan secara mendalam dan kedalaman data yang menjadi pertimbangan dalam penelitian ini (Soraya, 2017). Penelitian kualitatif dapat memperlihatkan pengalaman individu ataupun organisasi menghadapi masyarakat dalam kehidupan sehari-hari dan mempelajari tentang kelompok dan pengalamanpengalaman yang mungkin tidak diketahui sebelumnya (Taylor, 1975). Penelitian kualitatif deskriptif sendiri merupakan metode penelitian yang berlandaskan pada filsafat postpositivisme yang biasanya digunakan untuk meneliti pada kondisi objektif yang alamiah dimana peneliti berperan sebagai instrument kunci (Sugiyono, 2008), sementara itu metode deskriptif juga dapat digunakan sebagai metode yang melukiskan suatu keadaan objektif atau peristiwa tertentu berdasarkan fakta-fakta yang tampak atau sebagaimana mestinya yang kemudian diiringi dengan upaya pengambilan kesimpulan umum berdasarkan fakta-fakta historis tersebut.(Nawawi, 1994) 
Penelitian kualitatif memiliki karakteristik yang menjadi pedoman oleh peneliti, yakni (Bogdan, 1982):

1. Peneliti sendiri sebagai instrumen utama untuk mendatangi secara langsung sumber data

2. Mengimplementasikan data yang dikumpulkan dalam penelitian ini lebih cenderung katakata dibandingkan angka.

3. Menjelaskan bahwa hasil penelitian lebih menekankan kepada proses tidak semata-mata kepada hasil

4. Melalui analisis Induktif, peneliti mengungkapkan makna dari keadaan yang terjadi

5. Mengungkapkan makna sebagai hal yang esensial dari pendekatan kualitatif.

Berdasarkan dari karakteristik penelitian kualitatif diatas, dalam penelitian ini peneliti langsung berlaku sebagai peneliti utama (Key Instrument) yang mana melakukan proses penelitian secara langsung, mengumpulkan berbagai materi atau bahan yang berkaitan dengan Pemanfaatan Media Sosial Tik Tok Sebagai Media Kampanye Gerakan Cuci Tangan Di Indonesia untuk pencegahan Corona COVID-19.

Pada penelitian ini, subjek penelitian ini adalah video yang dibuat dengan memanfaatkan aplikasi Tik Tok pada akun World Health Organization (WHO) dan juga hastag \#safehands.sedangkan Objek penelitian yang merupakan variabel penelitian yang merupakan inti dari problematika penelitian (Soraya, 2017).Objek penelitiannya adalah Gerakan Kampanye cuci tangan oleh WHO di aplikasi tiktok.

\section{HASIL}

Tik Tok merupakan aplikasi Sosial Media yang menjadi budaya populer di Indonesia mulai awal tahun 2020 ini. Tik Tok sendiri dalam pelafalan bahasa cina di sebut Douyin yang merupakan aplikasi video musik yang pada awalnya digunakan untuk hiburan lipsync lagu oleh penggunanya, aplikasi ini dari berasal dari negeri Tiongkok yang diciptakan oleh ByteDance tahun 2016( https://tekno.kompas.com/read/2020/02/25/12320007/video-tiktok-malah-populerdi-instagram-mengapa-). Pada tahun 2017 aplikasi Tik Tok mulai masuk ke Indonesia, namun pada saat itu aplikasi ini dianggap "norak" dan ditolak oleh masyarakat Indonesia dan pada puncaknya pada Juli 2018 dilakukan pemblokiran aplikasi TikTok di Indonesia oleh Kementrian Komunikasi dan Informatika.

Pemblokiran aplikasi Tik Tok pada tahun 2018 dilakukan oleh Kominfo karena adanya sekitar tiga ribu laporan masyarakat yang masuk ke Kominfo menyoal konten negatif di aplikasi Tik Tok dan juga adanya laporan dari Kementerian Perempuan dan Perlindungan Anak serta Komisi Perlindungan Anak Indonesia akan banyaknya konten negatif di Tik Tok seperti 
pornografi, asusila, dan pelecehan agama di sana.( https://kominfo.go.id/content/detail/13331/inipenyebab-kominfo-putuskan-blokir-tik-tok/0/sorotan_media).

Ditahun 2020 saat ini, Tik Tok sudah menjadi budaya populer di Indonesia dan juga hampir secara global. Hal ini dapat terlihat dari data yang ada, bahwa Tik Tok menjadi aplikasi non-gaming kedua yang banyak diunduh pada 2019 yakni sebanyak 1,5 miliar kali diunduh di App Store dan Google Play.( https://www.liputan6.com/tekno/read/4155907/nyaris-salipwhatsapp-tiktok-jadi-aplikasi-terpopuler-kedua-di-dunia). Selain jumlah unduhan yang meningkat, pendapatan Tik Tok juga mengalami kenaikan mencapai US\$176,9 juta (sekitar Rp.2,4 triliun) dan ini merepresentasikan $71 \%$ dari total pendapatannya sejak pertama kali diluncurkan, yakni sebesar US\$247, 6juta (setara Rp.3,4triliun) (https://id.techinasia.com/perjalanan-tiktok-di-indonesia), dan ini membuat Tik Tok menjadi aplikasi non gaming nomor 7 dengan pendapatan tertinggi .

Perkembangan Tik Tok yang pada tahun 2017 yang masuk di Indonesia, lalu pada tahun 2018 di blokir oleh Kominfo dan di 2020 kini menjadi suatu budaya populer di Indonesia. Budaya populer sendiri dapat dilihat dalam empat konteks, yakni merupakan suatu budaya yang dibangun diatas kesenangan yang tidak substansial dan meringankan orang dari rasa jenuh bekerja sepanjang hari, budaya populer menghancurkan budaya tradisional, budaya menjadi masalah dalam perspektif ekonomi, budaya dan budaya populer Marx yang menetes dari atas (Bungin, 2008).Budaya populer sendiri memiliki karakteristik, yakni budaya populer menciptakan tren, memiliki bentuk yang seragam, dapat beradaptasi dengan baik sehingga mampu dinikmati oleh publik secara luas, bersifat sementara atau dapat diganti ketika terjadi masyarakat umum terganggu dengan produk budaya populer lainnya, daya tahannya mengikuti waktu selera publik, profitabilitas atau potensi keuntungan yang dapat diperoleh oleh pihakpihak terkait, pola konsumsi dan efek budaya populer yang dapat menghasilkan kesenangan dan gangguan (Mahanani, 2015).

Budaya Populer sangat erat kaitannya dengan budaya massa, karena budaya massa bisa juga disebut budaya populer yang dihasilkan melalui teknik-teknik industri produksi massa dan dipasarkan untuk mendapatkan keuntungan dari khalayak konsumen massa.Budaya massa sendiri berkembang karena semakin pesatnya perkembangan teknologi dan era konvergensi yang semakin nyata.Pada dekade sebelumnya media massa menjadi bagian dari budaya populer, di era digital saat ini membuat sosial media menjadi budaya populer dengan beragam keunikannya serta fenomena kehadirannya yang tidak bisa diduga sebelumnya.(Irwanto, 2017). Sosial media seperti Tik Tok menjadi budaya yang populer di Indonesia merupakan salah satu perwujudan dari dimana masyarakat Indonesia yang sudah terbiasa dengan perkembangan Teknologi serta sosial media dengan mrnggunakan gawai smartphoneuntuk memutar video lipsync. 
Aplikasi Tik Tok bisa menjadi budaya populer di Indonesia, karena beberapa alasan, yakni (Yang, Zhao, \& Ma, 2019)

1. Video Pendek yang dekat dengan realitas dan situasi umum

Video dan lagu yang berdurasi pendek yang dibuat oleh creator (sebutan untuk pembuat konten di tiktok) memiliki kedekatan realitas masyarakat, dan dibalut dengan hiburan, sains,dan fashion sebagai konten utama sehingga mudah menarik perhatian audiens.

2. Layanan Video Pendek yang sederhana

Pada Tik Tok para creator dibebaskan membuat konten video dengan durasi pendek (15 detik hingga sampai 1 menit), disini creator diberikan memudahkan untuk membuat konten, mulai dari pemilihan lagu yang sudah ada layanan "search" dan pada layanan pemilihan lagu ini juga memberikan kemudahan dengan mengklasifikasikan lagu yang ada, mulai dari genre hingga sampa klasifikasi yang sedang trending saat ini, bila creator tidak tahu judul lagu yang akan digunakannya maka creator bisa langsung memilih judul lagu pada video creator lain yang menggunakannya, sehingga proses produksi konten yang rumit dimasa lalu sudah diminimalisir.

3. Antar Muka Aplikasi yang Friendly

Dari semua layanan (fitur) yang memanjakan creator dan audience tidak akan maksimal penggunaanya bila tanpa antar muka yang mudah dan user friendly, Tik Tok menyediakan kemudahan itu sehingga pengguna Tik Tok dapat memilih antarmuka musik mereka sendiri, menambahkan efek khusus seperti keindahan dan gerak lambat, dan kemudian membuat video pendek musik favorit mereka.

4. Tingkat Produksi yang canggih

Tik Tok dapat mudah berkembang menjadi populer karena mereka menerapkan fungsi mendorong konten yang diproduksi secara akurat sesuai dengan preferensi dan kebutuhan pengguna, hal ini dapat terwujud karena teknologi yang digunakan cukup mumpuni sehingga video yang disuguhkan pada halaman utama related dengan pengguna.

5. Kebebasan untuk Pengguna

Aplikasi Tik Tok memberikan kebebasan bagi para penggunanya sesuai dengan teori komunikasi, yakni membantu masyarakat untuk mengekspresikan diri dan merekam kehidupan yang baik adalah makna dari keberadaan video tersebut. (Mancini dan Hallin, 2012). Setelah memasuki halaman beranda Tik Tok, itu adalah konten yang direkomendasikan oleh Tik Tok untuk para penonton. Pengguna ponsel dapat beralih secara bebas atau meluncur. Klik dua kali pada layar untuk konten yang Anda sukai untuk menyukai koleksi. Fungsi pesan di sisi kanan layar juga memungkinkan audiens untuk berpartisipasi dalam interaksi dan komentar secara real time. Fungsi pesan adalah fungsi penerusan, di mana pemirsa dapat membagikan video ini ke Whatsapp, Facebook, 
Instagram, Insta stories, Line, Telegram dan juga email. Operasinya sederhana dan nyaman, dan dapat memenuhi berbagai persyaratan pengguna dalam waktu singkat

6. Konten utama yang membahas trend saat ini.

Pengguna Tik Tok yang kebanyakan kaum millennial sangatlah mengikuti trend yang sedang berlaku saat ini, mulai dari trend kebugaran, interpetasi emosional, pemandangan indah, kecantikan dan gerakan fisik yang mewakili trend mode saat ini.

7. Efek Selebriti

Dengan semakin maraknya selebriti di Indonesia yang menggunakan aplikasi Tik Tok membuat masyarakat mengikutinya. Jika di tahun 2017 lalu sangat sedikit selebriti tanah air yang menggunakan Tik Tok, kini banyak sekali selebriti yang membuat akun Tik Tok mereka, dan memposting ulang ke akun sosial media mereka lainnya.

8. Pemasaran yang menarik

Tik Tok memasarkan aplikasi mereka dengan menarik, dengan mengurangi biaya ekspresi dan meningkatkan konten yang menyenangkan serta dapat berkontribusi pada penyebaran video dengan cepat (George \& Bennet, 2005).

Di awal maret 2020, Indonesia mengumumkan kasus pertama akan pandemik yang sedang menyerang beberapa negara yaitu pandemik karena virus Covid-19 atau dikenal dengan corona. Melihat jumlah korban jiwa yang banyak di beberapa negara seperti Tiongkok, Italia, Spanyol, Prancis dan Amerika dan juga mudahnya virus ini menular secara langsung dan tidak langsung, yakni bisa menular secara langsung lewat percikan batuk, bersin ataupun berbicara percikannya langsung mengenai orang lain. Cara tidak langsung pada penularan virus covid 19 adalah apabila seseorang menyentuh permukaan atau benda apapun yang sudah terkena atau terkontaminasi percikan atau tetesan dari seseorang yang terpapar covid-19, jika tanpa sadar seseorang menyentuh benda yang sudah terkontaminasi virus corona tersebut, dan orang tersebut menyentuh wajah seperti bagian hidung dan mulut dan tanpa mencuci tangan terlebih dahulu maka dia berisiko tertular virus covid-19.

Berdasarkan arahan World Health Organization (WHO) yang merupakan Organisasi Kesehatan di bawah naungan PBB memberikan saran untuk mencegah penularan virus corona, yakni Cuci tangan yang benar sesering mungkin, menerapkan social distancing, menghindari menyentuh mata, hidung dan mulut, melakukan aturan bersin dan batuk yang benar, jika mengalami demam, batuk, dan kesulitan bernapas untuk segera berobat. (https://www.cnbcindonesia.com/tech/20200316190412-37-145321/cara-mencegah virus corona versi- situs-who). Dalam pelaksanaan arahan WHO untuk menghentikan penularan virus corona ini, WHO mengkampanyekan gerakan mencuci tangan yang benar kepada masyarakat seluruh dunia lewat beragam media, termasuk lewat sosial media. Di Indonesia yang dimana Tik Tok 
sedang menjadi budaya populer, menjadi media untuk WHO mengkampanyekan gerakan mencuci tangan yang benar sesering mungkin.

\section{Gambar 1. Tampilan Akun Tik Tok milik World Healt Organization}

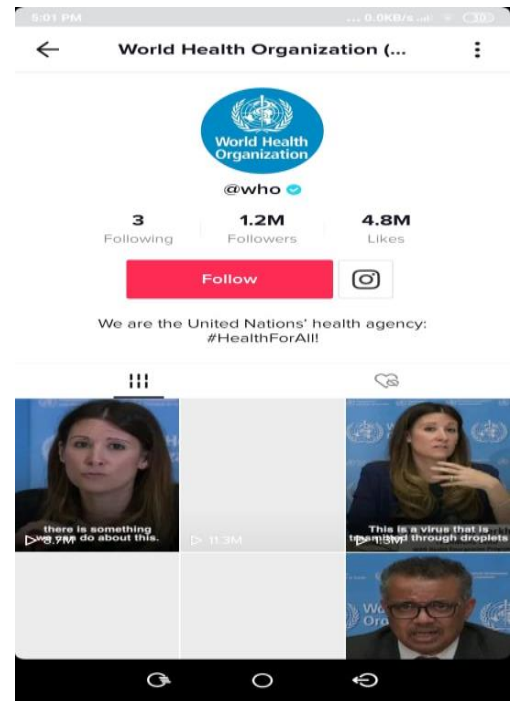

Terlihat dari tampilan akun ini berisikan nama ID akun, Bio akun, jumlah following, followers dan jumlah total likes yang diberikan dari semua video yang diupload oleh akun@who di Tik Tok.Pada tampilan akun ini juga terhubung dengan link sosial media Instagram ,sehingga pengguna bisa langsung melihat akun Instagram WHO.Pada selanjutnya adalah tampilan video singkat yang sudah diupload oleh akun WHO selama ini.Salah video yang diupload oleh akun @ who merupakan video singkat yang mengkampanyekan gerakan mencuci tangan yang benar sebagai salah satu cara memutus penularan virus corona.

Para pengguna Tik Tok yang berusia millennial lebih tertarik untuk menyaksikan video kampanye cuci tangan yang bertemakan professional namun dikemas dengan ringan tanpa adanya nilai pemaksaan didalam video tersebut.Salah satu narasumber memberikan contoh video dari creator akun@alodokter, yang dimana divideo tersebut terdapat empat orang dokter yang melakukan gerakan mencuci tangan yang benar diikuti dengan tulisan yang memberikan informasi tahapannya dan juga diiringi dengan lagu yang sedang trend di Tik Tok. Video tersebut sudah di sukai sebanyak 101,3 ribu kali dan di share sebanyak 8508 kali. Untuk pengguna Tik Tok yang sudah memiliki anak memberikan contoh berupa video dengan lagu yang mudah dicerna oleh anak-anak, sehingga anak-anak juga mengerti untuk melakukan cuci tangan yang benar di masa pandemic COVID-19 ini. Selain tema yang ringan dan mudah dicerna, faktor selebriti juga memainkan peran penting dalam kampanye ini, karena para selebriti yang sudah memiliki nama besar dan pengikut yang besar diaplikasi Tik Tok mempermudah penyaluran kampanye ini ke masyarakat luas. 
Gambar 2. Tampilan Video dari beberapa creator dengan menggunakan hastag \#safehands challenge

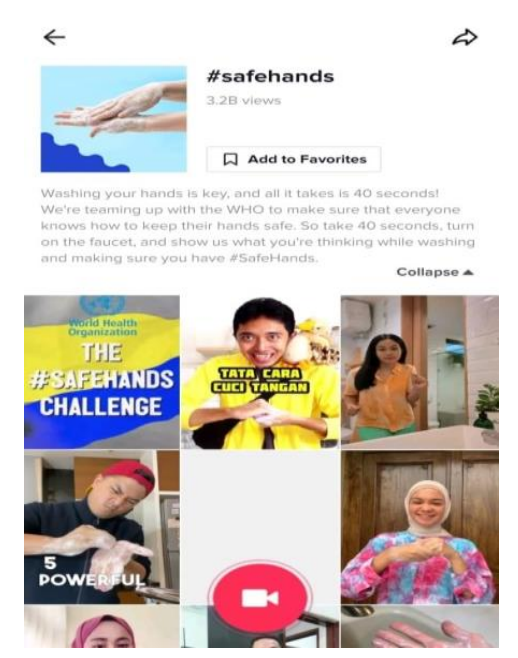

Dengan Penggunaan Tik Tok yang merupakan budaya populer saat ini di Indonesia, bisa menjadi media kampanye yang cukup ideal dalam mengkampanyekan gerakan mencuci tangan yang benar untuk memutus penularan virus COVID-19, karena budaya populer yang tidak memandang strata sosial lebih mudah untuk menjangkau masyarakat luas, terlebih sekitar $64 \%$ dari jumlah penduduk Indonesia sudah menggunakan internet, dan 160 juta penduduk Indonesia merupakan pengguna sosial media.Kampanye WHO di Tik Tok ini dengan menggunakan \#safehands challenge ini diikuti oleh para creator Tik Tok diseluruh dunia, walaupun mungkin para creator tidak semuanya fokus pada pesan kampanye ini, karena dalam sosial media ini juga banyak creator yang ikut memproduksi konten dengan hastag \#safehands challenge untuk mencari jumlah like dan followers lebih banyak. 


\section{KESIMPULAN}

Dengan menggunakan teknologi yang canggih Tik Tok memberikan algoritma proses yang sangat baik, dimana pengguna diberikan video yang sesuai dengan preferensi dan kebutuhan pengguna dengan akurat, kebebasan yang diberikan kepada pengguna sehingga pengguna bebas membagikan video yang ada di tiktok lewat berbagai cara, konten yang selalu mengikuti trend saat ini di masyarakat, Selebriti yang menggunakan dan menjadi creator di Tik Tok membuat masyarakat mengikuti idolanya, dan juga pemasaran Tik Tok sendiri yang unik dengan lebij konsen ke Konten yang ada didalamnya.

Tik Tok sebagai media populer menjadi media yang cukup ideal dalam melakukan kampanye gerakan mencuci tangan yang di prakasai oleh WHO lewat hastag \#safehands challenge, namun para pengguna lebih memilih video yang bertemakan professional dibidangnya (semisal dokter dalam kasus ini) namun ringan dan tidak menggurui.Dari banyak video yang mengikuti \#safehands challenge tidak semuanya berfokus dari pesan kampanye ini sendiri untuk memberitahukan gerakan tata cara mencuci tangan yang benar untuk memutus penularan virus COVID-19, karena banyak para creator hanya berfokus untuk mendapatkan lebih banyak suka dan followers. 


\section{DAFTAR PUSTAKA}

Sorrels. (2015). Globalizing Intercultural Communication. California: Sage Publications, Inc

Soraya, I. (2017). Personal Branding Laudya Cynthia Bella Melalui Instagram (Studi Deskriptif Kualitatif Pada Akun Instagram @Bandungmakuta). Jurnal Komunikasi, 8(2). https://doi.org/10.31294/JKOM.V8I2.2654

Bogdan, Robert, and Steven J. Taylor. Introduction to qualitative research methods: A phenomenological approach to the social sciences. John Wiley \& Sons, 1975.

Bogdan, R.C. dan S.K. Biklen. 1982. Qualitative Research for Education. Allyn and Bacon ,Inc. USA.

Bungin, B. (2008). Sosiologi Komunikasi (Teori, Paradigma, dan Discourse Teknologi Komunikasi di Masyarakat). Jakarta: Kencana Prenada Media Group.

Mahanani, P. A. (2015). Relasi Facebook Dengan Budaya Pop Dalam Perspektif Cultural Studies. Dialogia, 13(1), 79-88.

Irwanto. (2014). Studi Semiotika Sosial WEB Komunitas Kaskus Menegenai Kinerja Presiden SBY. Jurnal Komunikasi. Vol 5, No.1. Hal 16-29.

Kurniawan, B. (2018). Tik Tok Popularism and Nationalism: Rethinking National Identities and Boundaries on Millennial Popular Cultures in Indonesian Context. Proceedings of AICS Social Sciences.

Yang, S., Zhao, Y., \& Ma, Y. (2019). Analysis of the Reasons and Development of Short Video Application-Taking Tik Tok as an Example. 9th International Conference on Information and Social Science. https://doi.org/10.25236/iciss.2019.062

George, A. L., \& Bennett, A. (2005). Case studies and theory development in the social sciences. Cambridge, MA: MIT Press

Susilowati. (2018). Pemanfaatan Aplikasi Tiktok Sebagai Personal Branding Di Instagram (Studi Deskriptif Kualitatif Pada Akun @bowo_allpennliebe). Jurnal Komunikasi, 9(2), 176-185.

Irwanto. (2017). Media Sosial Penguat Eksistemsi Budaya Populer. Jurnal Ilmu Komunikasi (JIKA) Vol. IV No. 1 April 2017

Kurniawan, B. (2018). Tik Tok Popularism and Nationalism: Rethinking National Identities and Boundaries on Millenial Popular Cultures in Indonesian Context. Proceedings of AICSSocial Sciences. 